\title{
KEKUATAN BENTURAN KAPAL KAYU 5-7 GT SAAT MERAPAT KE DERMAGA: UPAYA UNTUK MENENTUKAN KETEBALAN MINIMAL LAMINASI FRP
}

\section{COLLISION STRENGHT OF 5-7 GT WOODEN FISHING VESSEL WHEN BERTH TO THE PIER: AN EFFORT TO DETERMINE THE MINIMUM THICKNESS OF FRP LAMINATION}

\author{
Muhamad Khoirul Anam ${ }^{1}$, Yopi Novita ${ }^{2 *}$, \& Budhi H. Iskandar ${ }^{2}$ \\ ${ }^{1}$ Program Studi Teknologi Perikanan Laut, FPIK-IPB University, Bogor, 16680 \\ ${ }^{2}$ Departemen Pemanfaatan Sumberdaya Perikanan, FPIK-IPB University, Bogor, 16680 \\ *E-mail: yopi1516@gmail.com
}

\begin{abstract}
This is an initial study in order to determain the minimum thickness of FRP (Fiber Reinforced Plastic) lamination on the size of a wooden vessel 5-7 GT (Gross Tonnage). The construction of FRP lamination aims to reduce direct contact of some parts of the ship with surrounding water and to reduce collision impact during berthing process as well especially to the hull. The laminating process is carried out by the skilled boat builders based on their experienced and knowledge. The purpose of this study is to obtain the collision strength of the ship that can be used as a refrence to determine the minimum thickness of FRP lamination. The descriptive-numeric methods were used in this research. Some data of the sampled vessel such as vessel type, main dimensions, speed and impact power were needed to be analyzed. There were 13 sampled vessels used in this research. The result showed that the vessel was included to towed or dragged gear. The main dimension of the vessel in average were $L_{o a} 9.5 \mathrm{~m} ; B_{\max } 3.2 \mathrm{~m} ; \mathrm{D} 1.2 \mathrm{~m}$ with displacement tonnage $13,6 \mathrm{ton} / \mathrm{m}^{3}$. The speed of the vessel decreased since the first collision in range of $0.4-1.0 \mathrm{~m} / \mathrm{s}$ or $20-75 \%$. The collision strength on that time was in range of 7.13-87.48 $\mathrm{kNm}$. Therefore, the impact strength that will be used as a reference in determining the thickness of the FRP laminate layer on wooden vessels is $87.48 \mathrm{kNm}$.
\end{abstract}

Keywords: collision strenght, fiberglass lamination, wooden vessel

\begin{abstract}
ABSTRAK
Kajian ini merupakan tahap awal dari kajian yang bertujuan menentukan ketebalan minimal lapisan laminasi FRP (Fiber Reinforced Plastic) pada kapal kayu ukuran 5-7 GT (Gross Tonnage). Konstruksi laminasi FRP bertujuan mengurangi kontak langsung bagian kapal dengan air disekitarnya serta mampu menahan benturan kapal ketika sandar pada dermaga khususnya bagian kasko kapal. Saat ini laminasi FRP dilakukan berdasarkan keahlian dan pengalaman yang dimiliki oleh pengrajin. Tujuan dari kajian ini untuk mengetahui kekuatan benturan pada kapal yang akan dijadikan acuan untuk menentukan ketebalan laminasi FRP. Metode yang digunakan adalah dengan identifikasi dimensi utama kapal, kecepatan kapal dan kekuatan benturan yang kemudian dianalisis secara deskriptif numerik. Data diperoleh dari 13 kapal sampel selama bulan Oktober-Desember 2019. Hasil dari penelitian ini menunjukkan bahwa kapal yang digunakan termasuk towed or dragged gear. Dimensi utama kapal dengan rata-rata $\mathrm{L}_{\mathrm{oa}} 9,5 \mathrm{~m} ; \mathrm{B}_{\max } 3,2 \mathrm{~m}$; D 1,2 m dengan ton displacement 13,6 ton $/ \mathrm{m}^{3}$. Kecepatan kapal ketika terjadi benturan pertama mengalami penurunan berkisar $0,4-1,0 \mathrm{~m} / \mathrm{s}$ atau sekitar 20-75\%. Kekuatan benturan yang terjadi pada kapal ketika benturan pertama berkisar 7,13-87,48 kN'm. Oleh karena itu, kekuatan bentur yang akan dijadikan acuan dalam menentukan ketebalan lapisan laminasi FRP pada kapal kayu adalah sebesar 87,48 kN'm.
\end{abstract}

Kata kunci: laminasi fiberglass, kapal kayu, kekuatan benturan 


\section{PENDAHULUAN}

Kajian ini merupakan tahap awal dari kajian yang bertujuan untuk mendapatkan ketebalan minimal lapisan laminasi FRP (Fiber Reinforced Plastic) pada kapal kayu. Pembuatan standar minimal jumlah lapisan laminasi FRP diperlukan agar tujuan melaminasi kapal kayu dengan lapisan FRP terpenuhi. Tujuan melaminasi kapal kayu dengan FRP adalah untuk melindungi material kasko kapal yang terbuat dari kayu agar tidak berinteraksi langsung dengan air laut. Hal ini dimaksudkan agar umur teknis kayu kapal, terutama di bagian kasko menjadi lebih tahan lama. Kelemahan dari penggunaan material kayu adalah mudah lapuk, sehingga umur teknis kapal menurun (Sunardi et al., 2019). Tebal lapisan laminasi FRP tidak boleh pula terlalu tebal, karena akan mengakibatkan kapal menjadi lebih berat. Apabila ini terjadi, maka kemampuan kapal untuk menampung beban muatan maksimum akan berkurang. Sebagaimana dinyatakan oleh Palembang et al. (2013), bahwa jumlah lapisan laminasi FRP semakin banyak, akan mengakibatkan bobot kapal bertambah berat, sehingga dapat mengurangi jumlah beban maksimal yang mampu dimuat oleh kapal. Akan tetapi, ketebalan lapisan laminasi FRP pun harus mampu menahan gaya benturan yang terjadi saat kapal mengalami benturan yang disebabkan oleh kapal lain yang akan merapat ke dermaga. Benturan yang terlalu keras, apabila mengenai lapisan laminasi FRP yang terlalu tipis, dikhawatirkan akan mengakibatkan retakan atau bahkan pecahnya laminasi FRP yang melapisi kapal.

Fenomena benturan kapal, umumnya terjadi di sekitar dermaga pelabuhan tempat bersandarnya kapal-kapal berukuran kecil, 5-7 GT, sebagaimana terdapat di Pangkalan Pendaratan Ikan (PPI) Cituis-Tangerang. Benturan ini tidak terelakkan, terutama saat kapal hendak merapat ke dermaga di antara keberadaan kapal lainnya yang telah berada di sekitar dermaga sebelumnya. Kapal-kapal berukuran kecil (5-7 GT) umumnya bersandar/parkir di dermaga dengan posisi yang saling berdekatan. Posisi sandar kapal yang saling rapat di dermaga ini, mengakibatkan kapal yang akan merapat di dermaga tidak bisa mengelakkan benturan. Proses benturan yang dimaksud dimulai dari kapal mematikan mesin penggerak untuk memasuki dermaga, kemudian secara tidak sengaja kapal yang berjalan untuk mencapai posisi sandar mengalami tubrukan sebanyak 3-4 kali. Kondisi tersebutlah yang mengakibatkan badan kapal mengalami kerusakan jika terjadi secara terus-menerus. Oleh karena itu, ketebalan lapisan laminasi FRP haruslah optimal, yaitu mampu melindungi kasko kapal dari sentuhan air laut, akan tetapi mampu menahan gaya benturan maksimum dari kapal yang menabraknya saat akan merapat ke dermaga.

Berdasarkan hasil pengamatan peneliti sebelumnya, di beberapa lokasi, yaitu di PP (Pelabuhan Perikanan) Muara AngkeJakarta Utara, Tanjung Lelehan-Banten dan di PPI Cituis-Tangerang, ketebalan lapisan laminasi sangat tergantung pada kebiasaan pengrajin kapal setempat. Demikian pula dengan jenis material FRP yang digunakan. Ketebalan lapisan laminasi FRP yang digunakan oleh pengrajin kapal di ke-3 lokasi tersebut berkisar antara 8-9 lapisan laminasi FRP. Berdasarkan hasil kajian Ma'ruf (2013) dan Marzuki et al. (2017), saat ini belum ada acuan khusus dalam melakukan laminasi kapal kayu, sehingga pengrajin melakukan laminasi berdasarkan keahlian dan pengalaman yang dimiliki. Laminasi sendiri merupakan teknik melapisi bagian tertentu dengan merekatkan lapisan atau lembaran dengan bahan material campuran perekat khusus (Patria \& Pribadi, 2017). Adapun bahan material yang digunakan untuk melakukan laminasi umumnya menggunakan CSM (Chopped Strand Mat), WR (Woven Roving), Catalist dan resin Marasabessy \& Siagian, 2016). Demikian pula material yang digunakan oleh para pengrajin kapal di ke-3 lokasi tersebut, juga 
menggunakan material WR, CSM dan resin.

Berdasarkan pemaparan di atas, maka tujuan penelitian ini adalah untuk mendapatkan gaya benturan kapal yang akan dialami kapal saat akan merapat ke dermaga. Informasi besarnya gaya benturan yang dialami kapal saat tertabrak oleh kapal lain yang sedang bergerak merapat ke dermaga, akan menjadi dasar acuan untuk menentukan ketebalan minimal lapisan laminasi FRP yang nantinya akan ditentukan dalam penelitian lanjutan setelah ini.

\section{METODE PENELITIAN}

\subsection{Waktu dan Tempat Penelitian}

Penelitian ini dilakukan pada bulan Oktober-Desember 2019 dan dilakukan di PPI Cituis-Tangerang.

\subsection{Pengumpulan Data}

Jenis data yang dikumpulkan di PPI Cituis (Tangerang) terdiri dari: dimensi utama kapal dengan mengukur panjang kapal (Loa), lebar kapal (B), tinggi kapal (D) dan draft kapal (d) (Susanto et al., 2011). Data dimensi utama kapal tersebut diperoleh dengan cara pengukuran langsung terhadap kapal-kapal penangkap ikan yang terdapat di PPI Cituis. Setelah dimensi utama kapal diperoleh maka akan ditentukan GT kapal dengan menggunakan rumus sesuai peraturan (PerMen Perhub PM 8/1/117 2013).

$G T=0,25 \times V$

Keterangan : $V=L \times B \times D \times f ; f=0,7$

Data dimensi utama kapal tersebut selanjutnya diolah untuk memperoleh nilai $\mathrm{Cb}$ (block coefficient) dengan menggunakan rumus (Fyson, 1985).

$C b=\frac{\nabla}{L_{w 1} \times B \times D}$.

Keterangan: $L_{w l}=$ panjang garis air; $B=$ lebar kapal; $D=$ tinggi kapal.
Selain data dimensi utama kapal, juga dilakukan pengumpulan data kecepatan laju kapal sesaat sebelum terjadi benturan. Pengukuran kecepatan laju kapal dilakukan dengan menggunakan alat bantu GPS (Global Positioning System) Garmin 78s yang dipasang di atas kapal yang melaju dan akan merapat di dermaga. GPS juga digunakan untuk mendapat data jarak dan waktu antara kapal yang bergerak dengan kapal yang akan ditabrak. Selanjutnya, data jarak dan waktu yang diperoleh dari GPS, dengan menggunakan persamaan (3) selanjutnya dihitung kecepatan (v) kapal yang dihasilkan.

$V=\frac{s}{t}$

Keterangan: $V=$ kecepatan; $S=$ jarak; $t=$ waktu.

\subsection{Analisis Data}

Analisis data dilakukan untuk mendapatkan kekuatan benturan maksimal yang diterima oleh bagian kapal yang menerima benturan dengan menggunakan pendekatan rumus OCDI (The Overseas Coastal Area Development Institute of Japan) (2009).

$E=\frac{M s \times V^{2}}{2} \times C_{m} \times C_{e} \times C_{s} \times C_{c}$

Keterangan: $E=$ energi benturan kapal $(\mathrm{kN} \cdot \mathrm{m}) ; V=$ Kecepatan kapal saat merapat $(\mathrm{m} / \mathrm{det}) ; M_{s}=$ Berat kapal yang diambil dari ton displacement kapal; $C_{m}=$ koefisien massa; $C_{e}=$ Koefisien eksentrisitas; $C_{s}=$ Koefisien kekerasan (1); $C_{c}=$ Koefisien bentuk dari tambatan (1).

Penghitungan koefisien massa $\left(\mathrm{C}_{\mathrm{m}}\right)$ dengan menggunakan rumus:

$C_{m}=1+\frac{\pi}{2 C_{b}} \frac{d}{B}$

Keterangan: $C_{b}=$ Koefisien blok kapal $\left(\right.$ ton $\left./ \mathrm{m}^{3}\right) ; d=$ draft kapal $(\mathrm{m}) ; \pi=3,14 ; B=$ lebar kapal (m). 
Selanjutnya, penghitungan koefisien eksentrisitas $\left(\mathrm{C}_{\mathrm{e}}\right)$ dengan menggunakan rumus:

$C_{e}=\frac{1}{1+\left({ }^{(/ / r}\right)^{2}}$

$r=\left(0,19 C_{b}+0,11\right) L_{p p}$

Keterangan: $l=$ jarak sepanjang permukaan air dari pusat berat kapal sampai titik sandar kapal (m) atau sama dengan $1 / 4$ panjang total kapal ( $1 / 4$ Loa); $r=$ jari-jari putaran di sekeliling pusat berat kapal pada permukaan air (m); $C_{b}=$ koefisien blok; $L_{p p}=$ panjang garis air (m)

Secara deskriptif, akan dianalisis bentuk kerusakan yang terjadi pada setiap kelompok GT kapal dan posisi kerusakan yang terjadi.

\section{HASIL DAN PEMBAHASAN}

\subsection{Profil Kapal Kayu Penangkap Ikan}

Data yang diperoleh di lapang meliputi dimensi utama kapal dan kecepatan kapal ketika bergerak merapat ke dermaga di antara kapal-kapal yang sedang sandar di sekitar dermaga. Data dimensi utama kapal meliputi panjang kapal, lebar kapal, tinggi kapal dan draft kapal merupakan data yang diperoleh dari pengukuran langsung pada 13 kapal sampel yang ada di PPI Cituis. Selanjutnya nilai GT dan ton displacement $(\Delta)$ diperoleh dari hasil olahan data dimensi utama kapal dengan menggunakan masingmasing persamaan (1) dan (2). Kesemua nilai tersebut disajikan pada Table 1 .

Dari data tersebut (Table 1), untuk dimensi utama kapal memiliki rata-rata ukuran yang sama yaitu dengan panjang kapal 9,5 m, lebar 3,1 $\mathrm{m}$ dan tinggi 1,2 $\mathrm{m}$. Jenis alat tangkap yang dioperasikan oleh ke-13 kapal sampel adalah mini trawl atau pukat gardan. Ditinjau dari metode pengoperasian alat tangkap yang dioperasikannya, maka ke-13 kapal sampel tergolong kelompok kapal towed or dragged gear (Purwanto et al., 2016). Pada Table 2 disajikan perbandingan antara nilai L/B, L/D dan B/D kapal yang dijadikan sampel dengan kapal kelompok towed or dragged gear hasil penelitian yang dilakukan oleh Iskandar \& Pujiati (1995).

Informasi terkait nilai rasio dimensi utama kapal dapat digunakan untuk menilai secara aman kemampuan kapal ditinjau dari kestabilan kapal (dari nilai B/D), resistensi kapal (dari nilai L/B) dan kekuatan longitudinal kapal (dari nilai L/D). Pada Table 2 terlihat bahwa kisaran nilai L/B dan L/D kapal sampel mendekati nilai minimal kapal

Table 1. Main dimension, GT and tonnes displacement of fishing vessel $(\Delta)$.

\begin{tabular}{ccccccc}
\hline Ship & $\mathrm{L}_{\mathrm{oa}}(\mathrm{m})$ & $\mathrm{B}_{\max }(\mathrm{m})$ & $\mathrm{D}(\mathrm{m})$ & draft $(\mathrm{m})$ & $\mathrm{GT}\left(\mathrm{m}^{3}\right)$ & $\Delta\left(\mathrm{ton} / \mathrm{m}^{3}\right)$ \\
\hline 1 & 8.3 & 3.0 & 1.2 & 0.97 & 5.23 & 11.16 \\
2 & 9.2 & 3.0 & 1.1 & 0.87 & 5.31 & 11.34 \\
3 & 9.2 & 3.4 & 1.0 & 0.77 & 5.47 & 11.68 \\
4 & 9.5 & 3.1 & 1.1 & 0.87 & 5.67 & 12.10 \\
5 & 9.1 & 3.1 & 1.2 & 0.97 & 5.92 & 12.64 \\
6 & 9.5 & 3.1 & 1.2 & 0.97 & 6.18 & 13.20 \\
7 & 9.2 & 3.5 & 1.1 & 0.87 & 6.20 & 13.23 \\
8 & 10.0 & 3.2 & 1.2 & 0.97 & 6.72 & 14.34 \\
9 & 10.0 & 3.5 & 1.1 & 0.87 & 6.74 & 14.38 \\
10 & 9.5 & 2.8 & 1.5 & 1.27 & 6.98 & 14.90 \\
11 & 10.5 & 3.5 & 1.1 & 0.87 & 7.07 & 15.10 \\
12 & 9.5 & 3.3 & 1.3 & 1.07 & 7.13 & 15.22 \\
13 & 10.0 & 3.0 & 1.5 & 1.27 & 7.88 & 16.81 \\
\hline
\end{tabular}

Source: Field Data. 
Table 2. Main dimension of fishing vessel 5-7 GT.

\begin{tabular}{lccc}
\hline & L/B & L/D & B/D \\
\hline $\begin{array}{l}\text { Main dimension of the } \\
\text { ship* }\end{array}$ & $2.63-3.39$ & $6.33-9.55$ & $1.87-3.40$ \\
$\begin{array}{l}\text { Towed } \text { or dragged gear } \\
\text { of ship group** }\end{array}$ & $2.86-8.30$ & $7.20-15.21$ & $1.25-4.41$ \\
\hline
\end{tabular}

Source: * Field Data

** Iskandar \& Pujiati (1995).

acuan. Hal ini menunjukkan bahwa ke-13 kapal sampel memiliki resistensi yang besar dengan kekuatan longitudinal kapal yang besar pula. Akan tetapi dengan kisaran nilai B/D yang relatif sama dengan kapal acuan, maka ke-13 kapal sampel memiliki stabilitas yang relatif sama dengan kapal acuan. Dalam Ayodhyoa (1972); Kalangi (2013), menyatakan bahwa stabilitas, resistensi dan kekuatan longitudinal kapal akan semakin besar apabila nilai B/D kapal semakin besar, nilai $L / B$ semakin besar dan nilai L/D semakin kecil.

\subsection{Kecepatan dan Kekuatan Benturan}

Kecepatan kapal diukur ketika mesin penggerak kapal dimatikan hingga mencapai titik posisi sandar yang diinginkan. Hal tersebut dilakukan untuk mengetahui kecepatan pertama ketika kapal mengalami benturan. Pada umumnya kecepatan kapal mengalami penurunan ketika terjadi benturan pertama kemudian akan menurun pada benturan kedua dan selanjutnya (Sarena et al., 2016; Ramdhani et al., 2019). Proses terjadinya benturan saat kapal akan merapat ke dermaga, diilustrasikan pada Figure 1a dan $1 b$.

Pada Figure $1 a$, diilustrasikan sebuah kapal yang akan merapat ke dermaga, di mana kapal yang akan merapat ke dermaga, bagian samping haluan kapal menabrak tiga kapal sebelum sampai ke depan dermaga. Lain halnya pada Figure $1 b$, diilustrasikan sebuah kapal yang akan merapat ke dermaga, menabrak 4 kapal lainnya sebelum sampai ke depan dermaga. Benturan saat terjadi tabrakan itulah yang harus diantisipasi pada saat penentuan struktur laminasi FRP yang akan diterapkan dari hasil akhir penelitian ini. Apabila beban gaya tubrukan atau beban bentur tersebut tidak diperhitungkan, maka lapisan FRP yang akan diaplikasikan pada kasko kapal, akan mudah retak atau bahkan pecah. Sehingga fungsi lapisan laminasi FRP yang bertujuan untuk melindungi kasko kapal tidak dapat terpenuhi. Hal ini dikarenakan, bagian laminasi FRP yang pecah atau retak, akan menjadi celah masuknya air laut ke kayu kapal. Berikut adalah kondisi bagian kapal yang menerima benturan, yang disajikan pada Figure 2.

Dari Figure 2 terlihat kondisi bagian lambung kapal yang tergores setelah mengalami benturan. Berdasarkan hasil pengamatan di lapang, diketahui kapal yang akan merapat ke dermaga melalui kapal-kapal yang terlebih dahulu berada di sekitar dermaga, sehingga terjadi tubrukan secara tidak sengaja 3-4 kali, baik pada kapal yang sama maupun dengan kapal yang berbeda. Kecepatan kapal saat mengalami benturan disajikan dalam bentuk grafik, yang dikelompokkan menjadi 3 kelompok yaitu kapal 5 sd < 6 GT (Figure 3), 6 sd $<7$ GT (Figure 4) dan 7 GT (Figure 5).

Dari (Figure 3) terlihat bahwa kecepatan tertinggi yang terjadi pada benturan pertama adalah pada kapal 5 yaitu 1,3 m/s. Kemudian untuk kecepatan benturan pertama terendah terjadi pada kapal 2 yaitu 0,4 $\mathrm{m} / \mathrm{s}$. Secara umum terlihat adanya fenomena bahwa kecepatan kapal akan menurun setelah mengalami benturan. Kecepatan laju ka- 


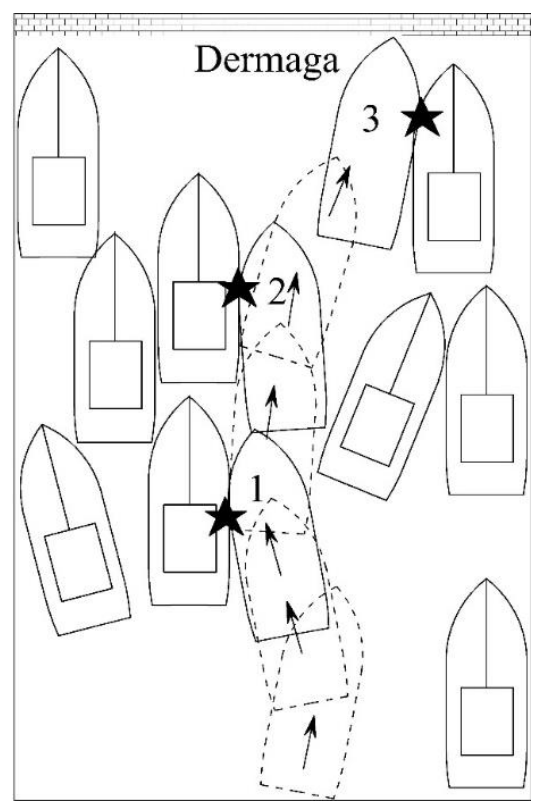

(a) with 3 times collision

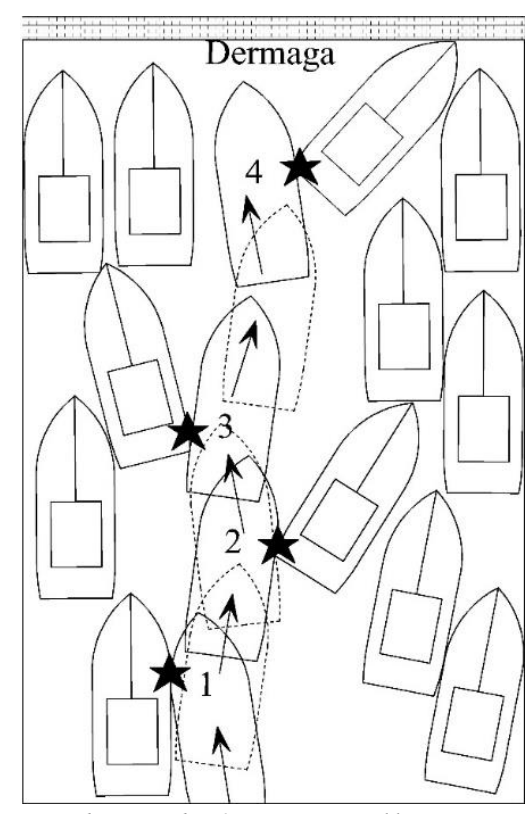

(b) with 4 times collision

Figure 1. The condition of the part of the fishing vessel that receives a collision $\star \quad$ : Point of impact on the ship.

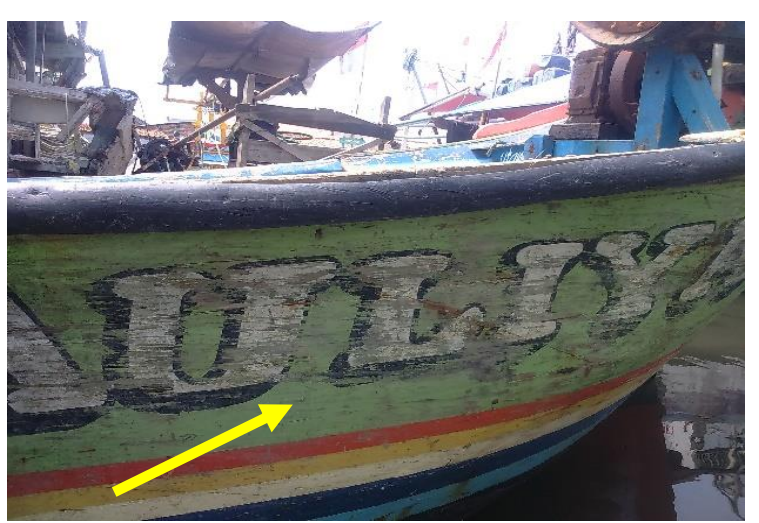

Figure 2. The condition of the fishing vessel's part experiencing a collision.

pal akan berkurang pada benturan pertama kali, kedua dan selanjutnya, seperti yang terjadi pada kapal 5, 4 dan 1. Kecepatan laju kapal mengalami penurunan setelah benturan pertama antara $0,2-0,5 \mathrm{~m} / \mathrm{s}$ atau sekitar 20-80\% dari kecepatan awal/sebelum benturan. Fenomena berbeda terjadi pada kapal 2 dan 3, setelah benturan berakhir mengalami penambahan kecepatan. Hal tersebut terjadi karena nakhoda kapal menambah kecepatan laju kapal untuk mencapai titik posisi sandar yang diinginkan, dan ini terjadi karena kapal belum mencapai titik sandar yang diharapkan oleh nakhoda kapal.

Selanjutnya adalah analisis kecepatan dengan jumlah benturan yang terjadi pada kapal 6-< 7 GT (Figure 4). Berdasarkan gambar tersebut, kecepatan tertinggi terjadi pada benturan pertama adalah kapal 6 dan 10 yaitu $0,7 \mathrm{~m} / \mathrm{s}$. Kemudian untuk kecepatan benturan pertama terendah terjadi pada kapal 7 dan 9 yaitu $0,5 \mathrm{~m} / \mathrm{s}$. Dari gambar tersebut diperlihatkan juga penurunan kecepatan cukup drastis terjadi pada kapal 6 ketika mengalami benturan kedua yaitu 0,2 $\mathrm{m} / \mathrm{s}$. Akan tetapi pada kapal 6 juga terjadi peningkatan kecepatan laju kapal pada benturan ketiga yaitu sebesar $0,1 \mathrm{~m} / \mathrm{s}$. Dengan demikian penurunan kecepatan laju kapal setelah benturan pertama terjadi antara 0,3$0,5 \mathrm{~m} / \mathrm{s}$ atau sekitar $20-75 \%$ dari kecepatan awal.

Terakhir adalah analisis kecepatan dengan jumlah benturan yang terjadi pada kapal 7 GT untuk hasil data disajikan pada 


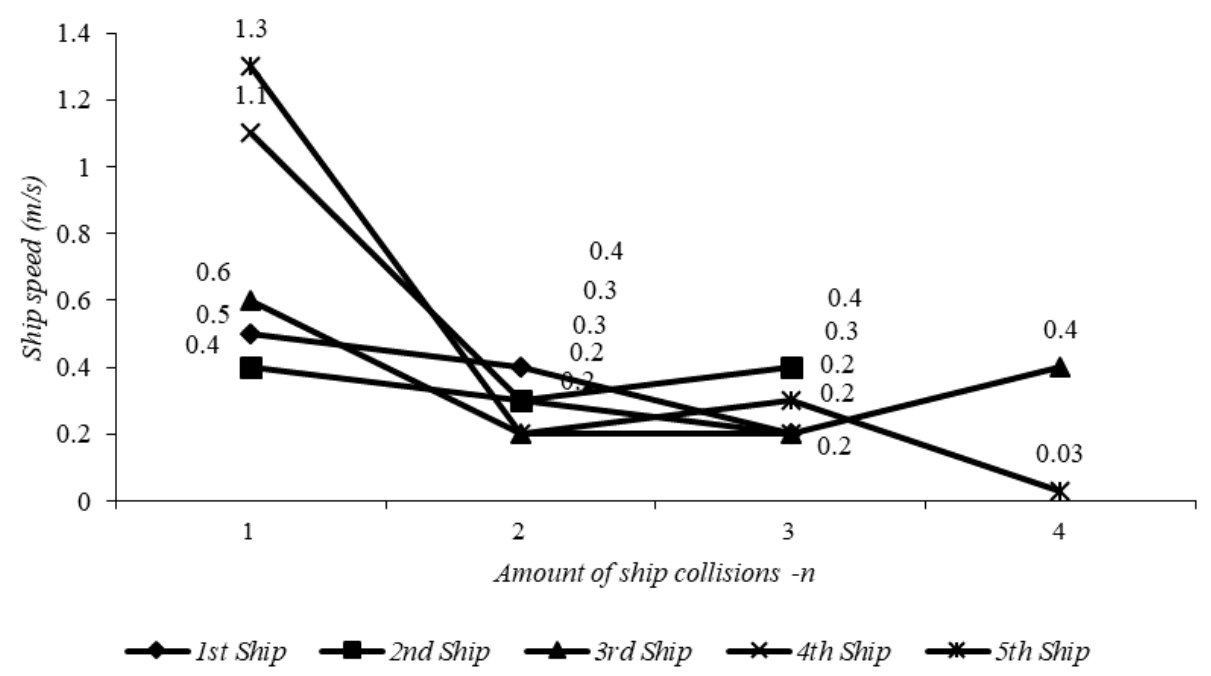

Figure 3. The fishing vessel speed when experiencing collisions, on 5-<6 GT fishing vessel.

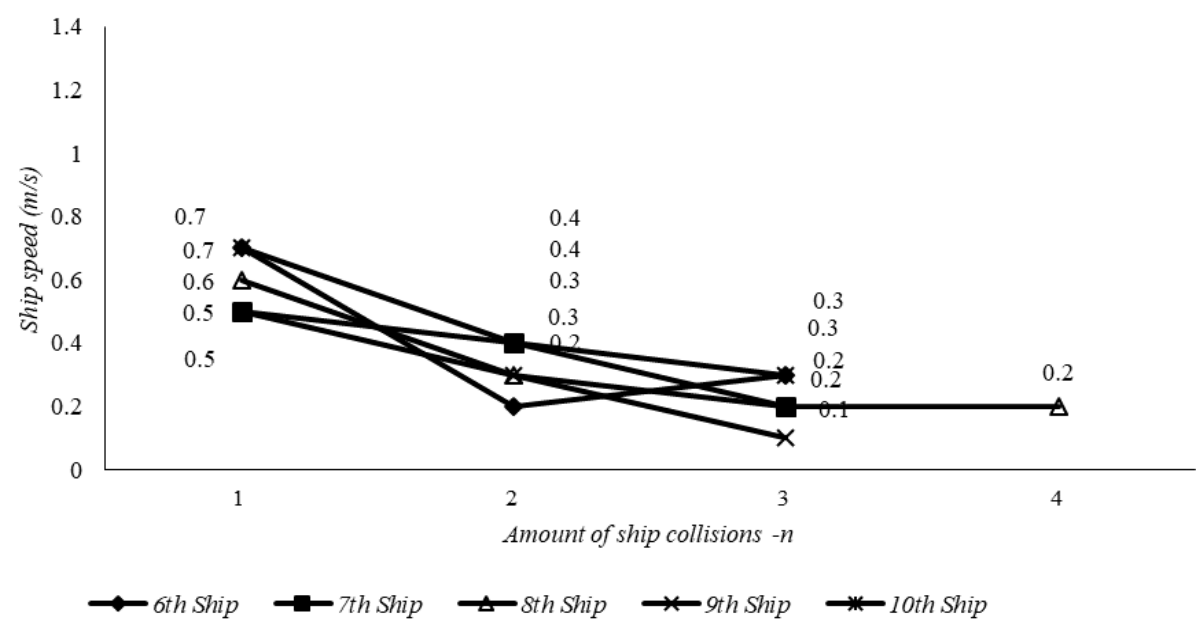

Figure 4. The fishing vessel speed when experiencing collisions, on 6-< 7 GT fishing vessel.

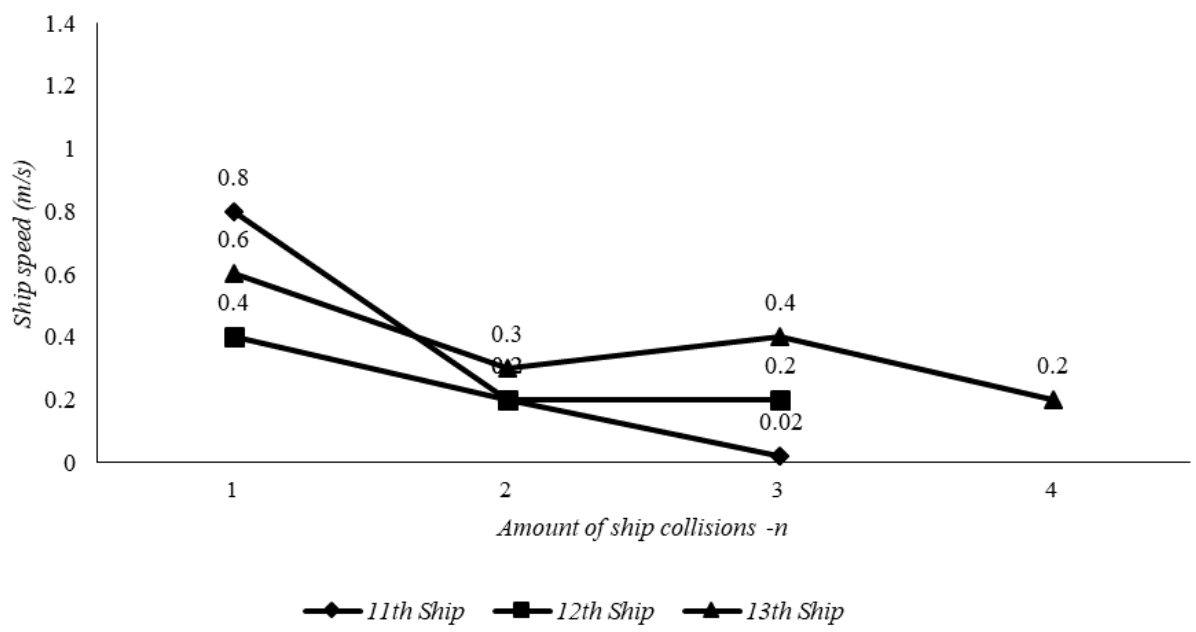

Figure 5. The fishing vessel speed when experiencing collisions, on 7 GT fishing vessel. 
Figure 5. Ukuran kapal 7 GT, kecepatan tertinggi benturan pertama adalah pada kapal 11 yaitu $0,8 \mathrm{~m} / \mathrm{s}$. Kemudian untuk kecepatan terendah yang terjadi pada benturan pertama adalah pada kapal 12 yaitu $0,4 \mathrm{~m} / \mathrm{s}$. Dari gambar tersebut juga diperlihatkan penurunan kecepatan setelah terjadi benturan yang pertama, seperti yang terjadi pada kapal 11, 12 dan 13. Penurunan kecepatan laju kapal ukuran 7 GT pada benturan pertama berkisar antara 0,2-0,6 m/s atau 20-75\% dari kecepatan awal. Namun adanya peningkatan kecepatan laju kapal terjadi pada kapal 13 setelah benturan ketiga sebesar $0,1 \mathrm{~m} / \mathrm{s}$.

Berdasarkan Figure 3, 4 dan 5 terlihat kecepatan laju kapal mengalami penurunan setelah mesin penggerak kapal dimatikan yaitu antara 0,2-1 $\mathrm{m} / \mathrm{s}$ dan penurunan kecepatan laju kapal setelah benturan pertama adalah antara 20-75\% dari kecepatan awal. Hal tersebut sesuai dengan OCDI (2009), bahwa kecepatan kapal dengan ukuran kurang dari 100 GT akan melaju dengan kecepatan antara 0,5-1,0 m/s ketika melakukan sandar pada dermaga. Jika dibandingkan antara kelompok kapal 5-<6 GT, 6-<7 GT dan 7 GT, pada kecepatan laju kapal yang sama sebelum terjadinya benturan pertama, yaitu $0,6 \mathrm{~m} / \mathrm{s}$ mengalami penurunan yang hampir sama yaitu $0,3-0,4 \mathrm{~m} / \mathrm{s}$. Adanya kecenderungan yang sama untuk kecepatan laju kapal sebelum terjadi benturan pertama, kedua dan seterusnya. Hal tersebut terjadi karena dimensi utama dan daya mesin kapal yang digunakan tidak jauh berbeda.

Selanjutnya, dengan menggunakan persamaan (4) sampai (7) diperoleh kekuatan benturan pada tiap titik benturan. Analisis hubungan kekuatan benturan dengan kecepatan kapal disajikan pada Figure 6, 7 dan 8.

Pada Figure 6 terlihat bahwa kapal ukuran 5-< 6 GT, kekuatan bentur terbesar pada saat benturan pertama, terjadi pada kapal 5 yaitu dengan kekuatan bentur 87,48 $\mathrm{kN} \cdot \mathrm{m}$. Adapun kekuatan benturan pertama terendah terjadi pada kapal 2 dengan kekuatan benturan $7,13 \mathrm{kN} \cdot \mathrm{m}$. Penurunan ke- kuatan benturan terjadi akibat menurunnya kecepatan kapal ketika terjadi benturan (Satria et al., 2013). Dari gambar tersebut menunjukkan kekuatan benturan cenderung menurun setelah terjadi benturan pertama yang berkisar 4,3-85,4 $\mathrm{kN} \cdot \mathrm{m}$ atau $30-75 \%$ dari kekuatan benturan pertama. Kekuatan benturan kapal mengalami penurunan setelah terjadi benturan pertama, kedua dan seterusnya, namun ada beberapa kapal yang mengalami peningkatan kekuatan benturan seperti yang terjadi pada kapal 2, 3 dan 5 adanya peningkatan kekuatan benturan 2,6$4,9 \mathrm{kN} \cdot \mathrm{m}$. Hal tersebut terjadi akibat adanya usaha yang dilakukan nakhoda kapal untuk mencapai titik posisi sandar dengan mendorong atau menghidupkan mesin peng-gerak (Yahya et al., 2013; Wardani et al., 2014).

Selanjutnya adalah analisis kekuatan benturan dengan kecepatan pada kapal 6-<7 GT yang disajikan pada Figure 7. Pada Figure 7 terlihat bahwa pada kelompok kapal ukuran 6-<7 GT, kekuatan benturan terbesar pada benturan pertama, terjadi pada kapal 10 yaitu dengan kekuatan bentur sebesar 36,59 kN.m. Adapun kekuatan benturan pertama terendah terjadi pada kapal 7 dengan kekuatan benturan 12,10 kN.m. Dari gambar tersebut juga menunjukkan penurunan kekuatan bentur yang terjadi pada masing-masing kapal yang berkisar 4,3-24,6 $\mathrm{kN} \cdot \mathrm{m}$ atau $30-90 \%$ dari kekuatan benturan pertama. Namun, peningkatan kekuatan benturan setelah terjadi benturan kedua seperti yang terjadi pada kapal 6 yaitu $4,82 \mathrm{kN} \cdot \mathrm{m}$ dari yang semula $2,14 \mathrm{kN} \cdot \mathrm{m}$, sehingga peningkatan kekuatan benturan sekitar 2,7 kN.m. Perbedaan kekuatan benturan pertama terjadi pada kapal 6 dan 10, pada masing-masing kapal memiliki kecepatan sama yaitu $0,7 \mathrm{~m} / \mathrm{s}$. Hal tersebut terjadi karena dimensi rasio kapal berbeda sehingga memengaruhi pergerakan kapal saat terjadi benturan. Menurut Novita et al. (2014), ukuran dimensi rasio kapal yang proporsional akan memengaruhi pergerakan kapal.

Terakhir adalah analisis kekuatan benturan dengan kecepatan kapal pada kapal 


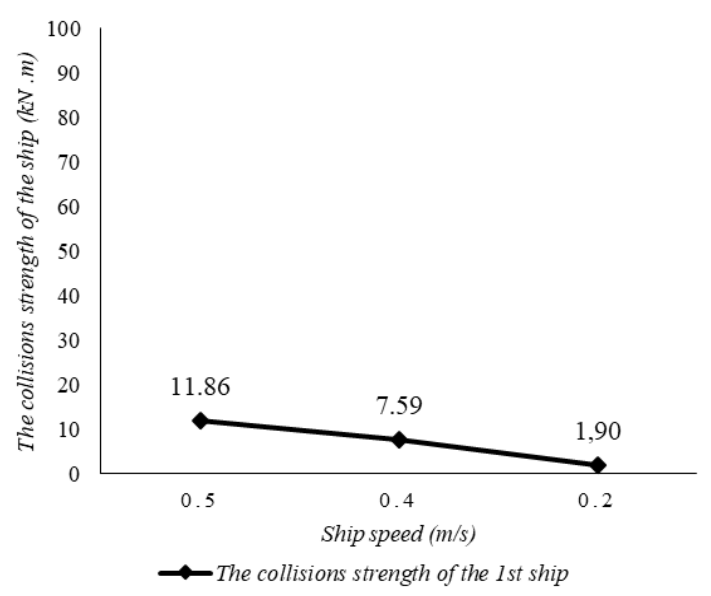

(a)

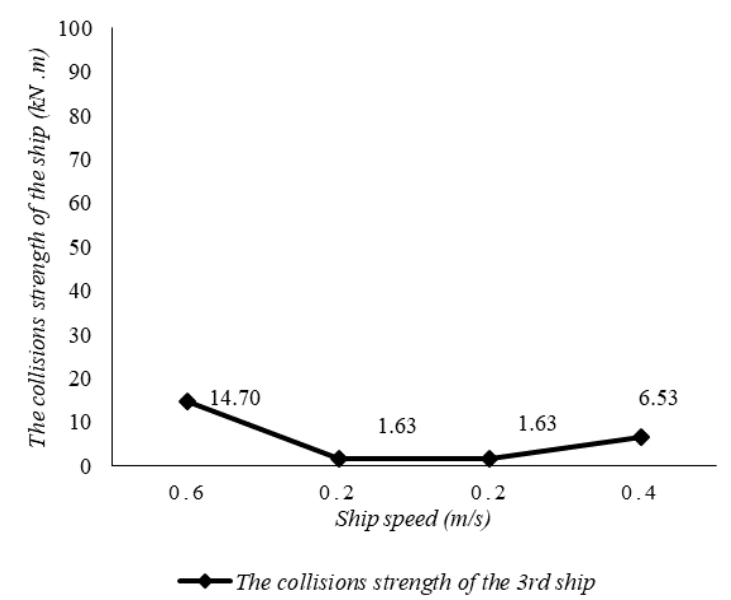

(c)

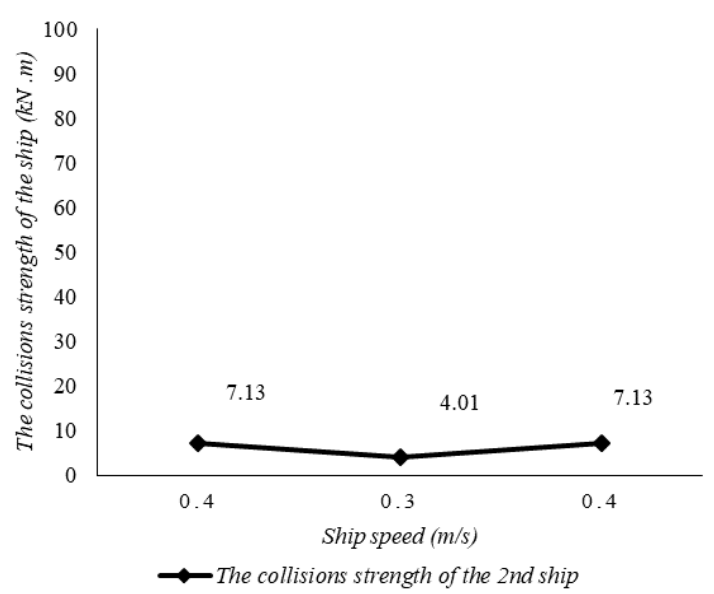

(b)

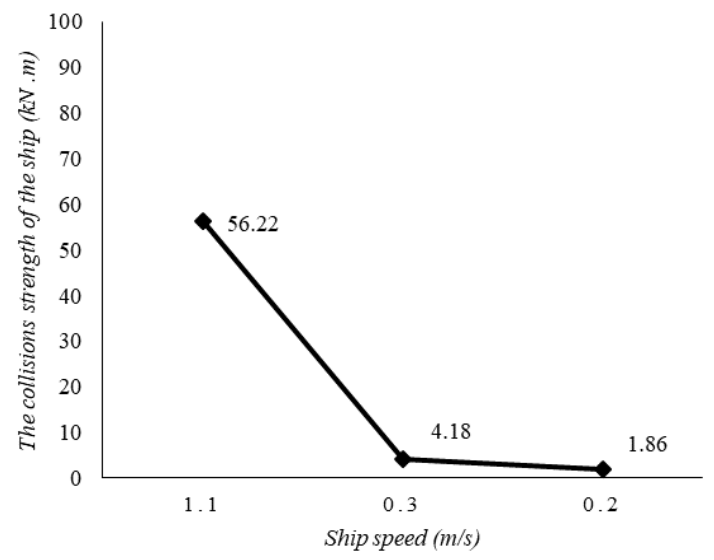

$\rightarrow$ The collisions strength of the 4th ship

(d)

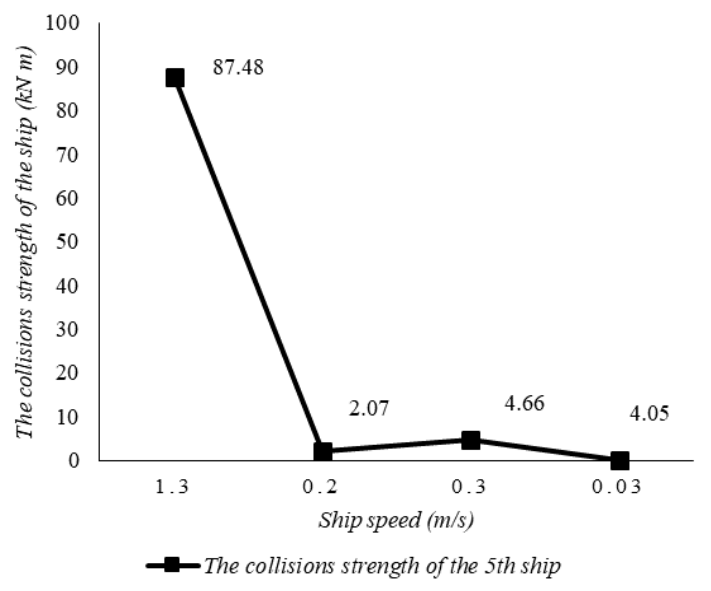

(e)

Figure 6. The relationship between 5- $<6$ GT fishing vessel speed and collisions strength (a) $1^{\text {st }}$ Ship; (b) $2^{\text {nd }}$ Ship; (c) $3^{\text {rd }}$ Ship; (d) $4^{\text {th }}$ Ship; (e) $5^{\text {th }}$ Ship.

7 GT yang disajikan pada Figure 8. Pada Figure 8 terlihat bahwa pada kelompok kapal 7 GT memiliki kekuatan benturan pertama terbesar, terjadi pada kapal 11 yaitu dengan kekuatan bentur sebesar 34,37 kN.m. Adapun kekuatan benturan pertama terendah terjadi pada kapal 12 yaitu dengan kekuatan bentur sebesar $10,07 \mathrm{kN} \cdot \mathrm{m}$. Adanya peruba- 
Kekuatan Benturan Kapal Kayu 5-7 GT Saat Merapat ke Dermaga ... .

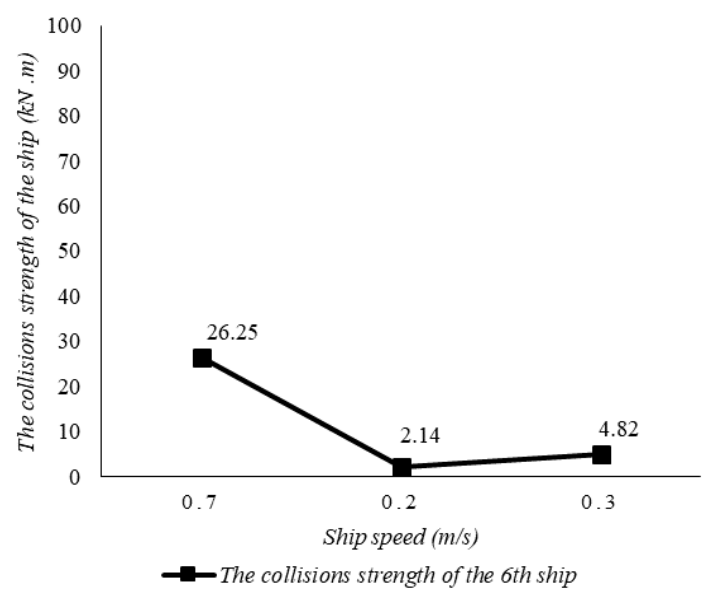

(a)

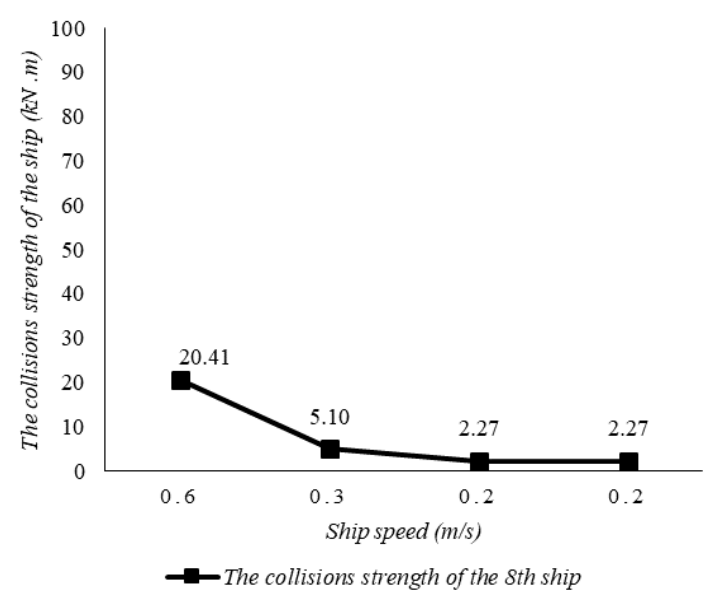

(c)

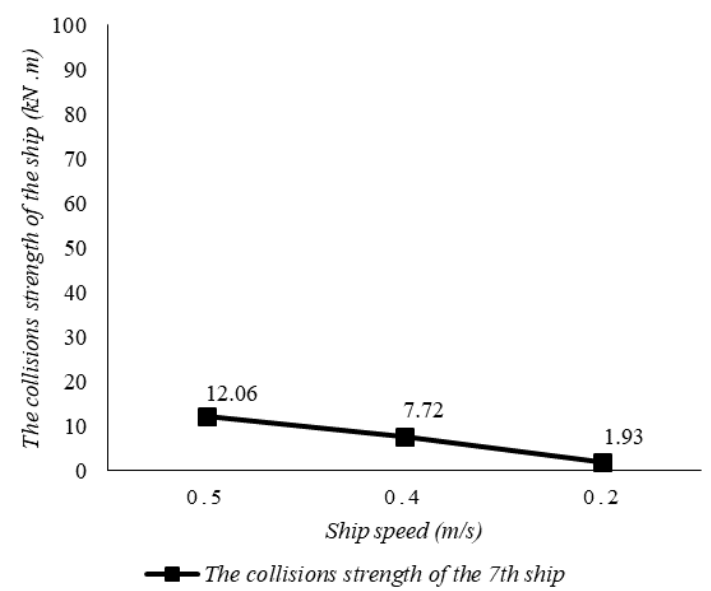

(b)

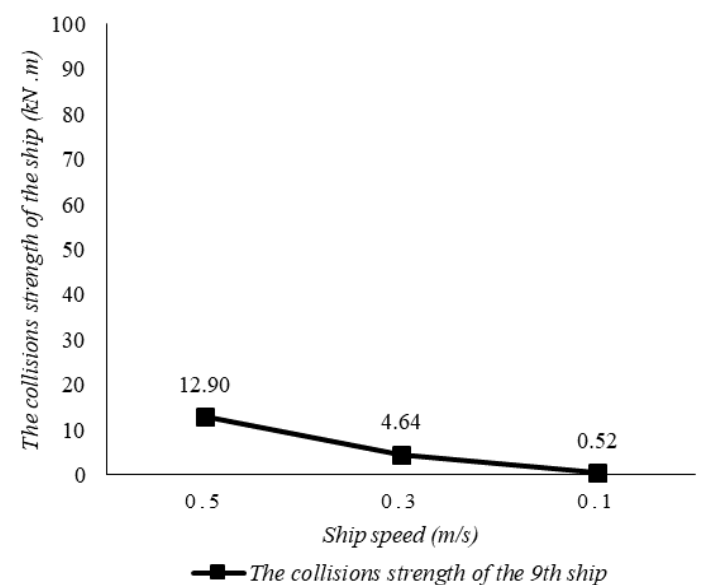

(d)

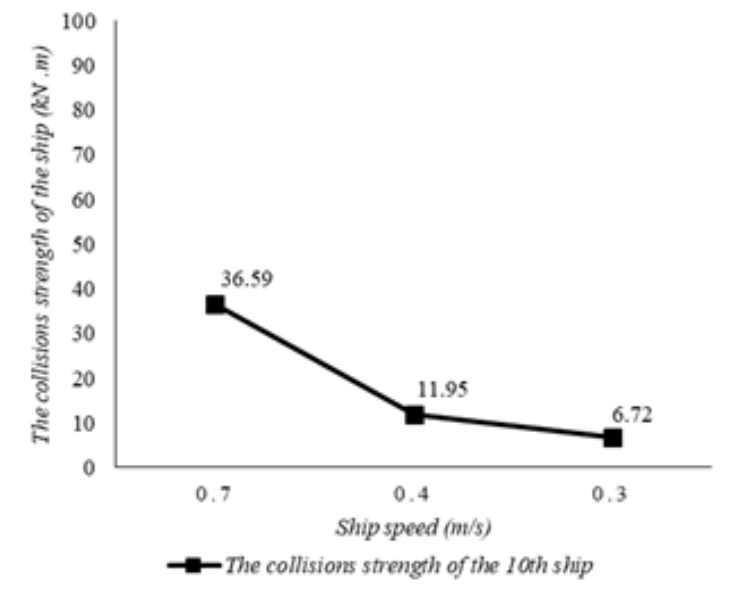

(e)

Figure 7. The relationship between 6- $<7$ GT fishing vessel speed and collisions strength (a) $6^{\text {th }}$ Ship; (b) $7^{\text {th }}$ Ship; (c) $8^{\text {th }}$ Ship; (d) $9^{\text {th }}$ Ship; (e) $10^{\text {th }}$ Ship.

han kekuatan benturan yang diperlihatkan dari gambar tersebut mengalami penurunan. Setelah benturan pertama yang berkisar 7,6$32,2 \mathrm{kN} \cdot \mathrm{m}$ atau $75-90 \%$ dari kekuatan bentu- ran pertama. Perubahan peningkatan kekuatan benturan terlihat berbeda pada kapal 13, hal tersebut diperlihatkan adanya peningkatan setelah benturan kedua sebesar 5,6 
$\mathrm{kN} \cdot \mathrm{m}$. Dari ketiga kapal yang memiliki ukuran 7 GT rata-rata mengalami penurunan kekuatan benturan mulai dari benturan pertama, kedua dan seterusnya hingga posisi kapal sudah sandar. Menurut Sitepu \& Baso (2016); Fauzan (2018), penurunan kekuatan benturan tersebut juga dipengaruhi kecepatan kapal yang semakin menurun akibat terlalu banyak mengalami benturan antar kapal sebelum mencapai tempat sandar yang dinginkan.

Berdasarkan Figure 6, 7 dan 8 terlihat kekuatan benturan kapal cenderung menurun ketika terjadi benturan yang pertama. Penurunan kekuatan benturan kapal setelah benturan pertama yang terjadi pada kapal 5-

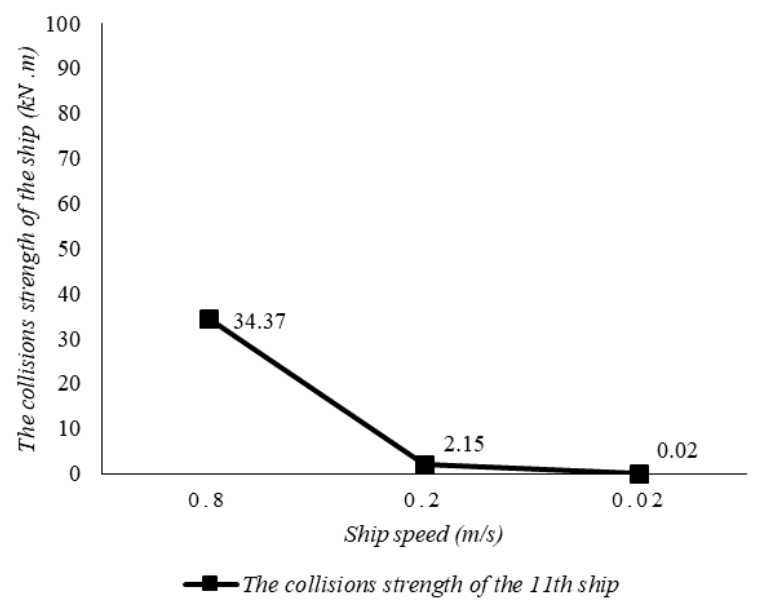

(a)
$<6$ GT, 6-< 7 GT dan 7 GT berkisar 3,1$85,4 \mathrm{kN} \cdot \mathrm{m}$ dan penurunan kekuatan benturan yang kedua, ketiga dan seterusnya berkisar 35-95 \% dari pertama kali kapal mengalami benturan. Jika dibandingkan dari ketiga kelompok ukuran kapal 5-<6 GT, 6-< 7 GT dan 7 GT adanya perbedaan kekuatan benturan yang terjadi ketika benturan pertama. Kondisi tersebut terjadi akibat adanya perbedaan kecepatan dan dimensi utama kapal (Svensson, 2009; Fauzan, 2018). Karena pada dasarnya seperti koefisien blok $(\mathrm{Cb})$, koefisien massa $(\mathrm{Cm})$, kecepatan kapal dan koefisien eksentrisitas (Ce), merupakan faktor yang akan meengaruhi besar kecilnya kekuatan benturan yang terjadi.

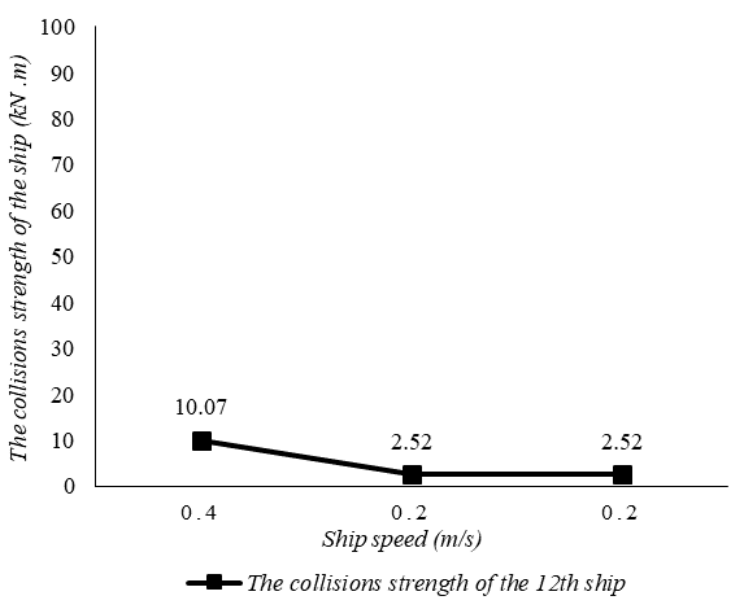

(b)

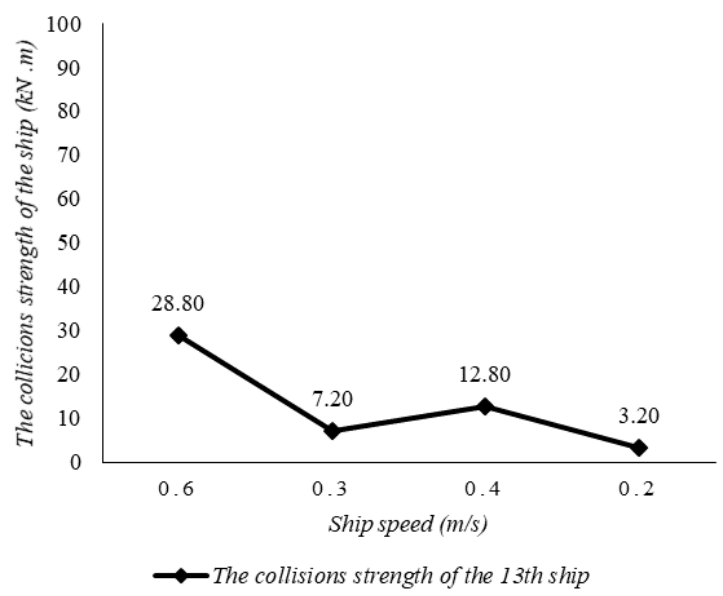

(c)

Figure 8. The relationship between 7 GT fishing vessel speed and collisions strength (a) $11^{\text {th }}$ Ship; (b) $12^{\text {th }}$ Ship; (c) $13^{\text {th }}$ Ship. 
Berdasarkan hasil observasi di lapangan, hasil benturan pada kapal yang tertabrak berupa lecet tipis pada kapal, atau dengan kata lain mengakibatkan cat kapal terkelupas. Dampak benturan akan lebih parah jika linggi haluan kapal yang membentur atau menabrak kapal, kerusakan bisa mengakibatkan sebagian material kayu pada kapal menjadi "penyok" di titik benturan atau membentuk cekungan. Biasanya nelayan sebelum linggi haluan membentur badan kapal yang lain, akan mengubah arah haluan sehingga benturan hanya diakibatkan oleh sisi badan kapal saja. Dampak benturan tidak terjadi pada tingkat kerusakan yang parah atau fatal, dikarenakan saat benturan terjadi, kapal bergerak dengan kecepatan sisa setelah mesin kapal dimatikan.

\section{KESIMPULAN}

Berdasarkan hasil penelitian, dapat disimpulkan bahwa kecepatan maksimal yang terjadi saat benturan pertama adalah $1,3 \mathrm{~m} / \mathrm{s}$ dengan kekuatan bentur sebesar $87,48 \mathrm{kN} \cdot \mathrm{m}$. Pada kecepatan bentur yang relatif sama, kekuatan bentur terbesar akan dihasilkan oleh kapal dengan ukuran terbesar. Dampak benturan terparah berupa lecet pada permukaan kayu kapal. Dampak benturan tidak sampai mengakibatkan perubahan konstruksi kayu pada kapal, dikarenakan posisi saat terjadi tubrukan, kapal bergerak dengan kecepatan sisa setelah mesin kapal dimatikan.

\section{UCAPAN TERIMA KASIH}

Ucapan terimakasih disampaikan kepada Dinas Perikanan Kabupaten Tangerang dan nelayan Cituis yaitu Bapak Ibun selaku wakil anggota kelompok nelayan PPI Cituis, Tangerang yang sudah membantu dalam persiapan dan pengambilan data lapang.

\section{DAFTAR PUSTAKA}

Ayodhyoa, A.U. 1972. Craft and gear.
Corespondence Course Centre. Jakarta. 66-68 p.

Fauzan. 2018. Perencanaan fender dermaga (jetty) kapal dengan bobot 10000 DWT. J. Ensiklopedia, 1(1):153157. https://doi.org/10.33559/eoj.v1i1.93

Fyson, J. 1985. Design of small fishing vessels. In Food and Agriculture Organization of the United Nations. England. 80-85 pp.

Iskandar, B.H. \& S. Pujiati. 1995. Keragaan teknis kapal perikanan di beberapa wilayah Indonesia (Laporan Penelitian). In Pemanfaatan Sumberdaya Perikanan, Fakultas Perikanan, Institut Pertanian Bogor. Bogor.

Kalangi, P.N.I. 2013. Perkembangan ukuran utama kapal pukat cincin di Sulawesi Utara. J. Ilmu dan Teknologi Perikanan Tangkap, 1(4): 128-134. https://doi.org/10.35800/jitpt.1.4.201 3.3828

Ma'ruf, B. 2013. Analisis kekuatan laminasi lambung kapal fiberglass yang menggunakan material multiaxial. $J$. Standarisasi, 16(1): 31-40. http://doi.org/10.31153/js.v16i1.81

Marasabessy, A. \& S. Siagian. 2016. Analisis keretakan pelat zona lambung kapal berbahan fiberglass. J. Kapal, 13(3): 151-152. https://doi.org/10.14710/kpl.v13i3.1 2400

Marzuki, I., A. Zubaydi, \& B. Ma'ruf. 2017. Kajian penerapan aturan klasifikasi pada laminasi struktur konstruksi lambung kapal ikan fiberglass 3 GT. J. Wave, 11(1): 15-22. https://doi.org/10.29122/jurnalwave. v11i1.2055

Novita, Y., N. Martiyani, \& E. Ariyani. 2014. Kualitas stabilitas kapal payang Pelabuhan Ratu berdasarkan distribusi muatan. J. IPTEKS Pemanfaatan Sumberdaya Perikanan, 1(1): 28-39. https://doi.org/10.20956/jipsp.v1i1.5 
8

Palembang, S., A. Luasunaung, \& F.P.T. Pangalila. 2013. Kajian rancang bangun kapal ikan fibreglass multifungsi 13 GT di galangan kapal CV Cipta Bahari Nusantara Minahasa Sulawesi Utara. J. Ilmu dan Teknologi Perikanan Tangkap, 1(3): 87-92.

https://doi.org/10.35800/jitpt.1.3.201 3.1410

Patria, A.A. \& T.W. Pribadi. 2017. Analisis teknis dan ekonomis pembangunan kapal ikan tradisional ukuran $<10$ GT berbahan kayu utuh dengan teknologi laminasi kayu mahoni. $J$. TEKNIK ITS, 6(1): G35-G41. http://doi.org/10.12962/j23373539.v 6 i1.22839

Purwanto Y., B.H. Iskandar, M. Imron, \& B. Wiryawan. 2016. Aspek keselamatan ditinjau dari stabilitas kapal dan regulasi pada kapal pole and line di Bitung, Sulawesi Utara. J. Marine Fisheries, 5(2): 181-191. https://doi.org/10.29244/jmf.5.2.181191

Ramdhani, M.A., S. Nugroho, \& L. Diana. 2019. Analisa performa savonius heliks untuk arus sungai di Indonesia menggunakan metode CFD. Prosiding Seminar Nasional Teknologi Terapan, Politeknik Elektronika Negeri Surabaya, Surabaya, 05 Agustus 2019. 5-9 pp. https://prosiding.polinema.ac.id/sngb r/index.php/sntt/article/view/251

Sarena, S.T., R.Y. Adhitya, C.R. Handoko, \& N. Rinanto. 2016. Aplikasi sistem peringatan tabrakan pada kapal berbasis data GPS menggunakan logika fuzzy. J. Ilmu Pengetahuan dan Teknologi, 20(2): 93-104. https://doi.org/10.31284/j.iptek.2016 .v20i2.48

Satria, A.Y., D.N. Fattah, D.A. Indrastono, \& H.I. Indarto. 2013. Evaluasi geoteknik dan struktur pada dermaga eksisting terminal peti kemas Semarang. J. Karya Teknik Sipil, 2(4): 309-319.

https://ejournal3.undip.ac.id/index.p hp/jkts/article/view/3949.

Sitepu, A.H. \& S. Baso. 2016. Performa design stripshield sea chest kapal basarnas tipe FRP36 berdasarkan water intake. J. Riset dan Teknologi, 14(1): 87-96.

http://journal.unhas.ac.id/index.php/j rtk/article/viewFile/691/491

Sunardi, Sukandar, E.Y. Sulkhani, \& M.A. Rahman. 2019. Repair technique for wooden fishing boats using fibreglass. In IOP Confrence Service Earth Environment Science. 370(1). https://doi.org/10.1088/17551315/370/1/012081

Susanto, A., B.H. Iskandar, \& M. Imron. 2011. Fishing vessel design and stability evaluation in Palabuhan Ratu (case study of PSP 01 trainingfishing vessel). J. Marine Fisheries, 2(2): 213-221.

http://103.10.105.65/index.php/jpsp/ article/view/6183

Svensson, H. 2009. Protection of bridge piers against ship collision. J. Steel Construction. 2(1): 21-32. https://doi.org/10.1002/stco.2009100 04

The Overseas Coastal Area Development Institute of Japan (OCDI). 2009. Chapter 5 earth pressure and water pressure. In: National Institute for Land and Infrastructure Management (MLTI). (ed.). Technical Standards and Commentaries for Port and Harbour Facilities In Japan. The Overseas Coastal Area Development Institute of Japan, Tokyo, Japan. 271-311 pp.

Wardani, G.A., Wijayanti, \& B.A. Murtomo. 2014. Penataan kampung nelayan Desa Bendar-Bajomulyo Kecamatan Juwana Kabupaten Pati. J. Imaji, 3(3): 227-238. 
Kekuatan Benturan Kapal Kayu 5-7 GT Saat Merapat ke Dermaga ...

https://ejournal3.undip.ac.id/index.p hp/imaji/article/download/5651/5439

Yahya, E., A. Rosyid, \& A. Suherman. 2013. Tingkat pemanfaatan fasilitas dasar dan fungsional dalam strategi peningkatan produksi di pelabuhan perikanan pantai Tegalsari kota Tegal Jawa Tengah. J. Ilmu dan
Perikanan Tangkap Tangkap, 2(1): $56-65$.

https://ejournal3.undip.ac.id/index.p hp/jfrumt/article/view/1741

Received : 1 June 2020

Reviewed : 27 September 2020

Accepted : 14 December 2020 